\title{
Pengaruh Motivasi Kerja, Kompetensi, Dan Kompensasi Terhadap Kinerja Pegawai Pada Kementrian Agama Kabupaten Bulukumba
}

\author{
Isfa Rukmana Ishak ${ }^{1}$, Achmad Gani ${ }^{2}$, Hasanuddin Damis ${ }^{3}$ \\ ${ }^{1}$ Magister Manajemen, Universitas Muslim Indonesia \\ 2,3 Fakultas Ekonomi dan Bisnis, Jurusan Manajemen, Universitas Muslim Indonesia \\ *Email Korespondensi: iezfhasagitarius@ymail.com
}

\begin{abstract}
Abstrak
Tujuan penelitian ini adalah apakah motivasi kerja, kompetensi dan kompensasi mempunyai pengaruh terhadap Kinerja Pegawai di Kantor Kementerian Agama Kabupaten Bulukumba. Metode penelitian menggunakan data primer dan data sekunder terhadap 55 orang responden. Metode pengambilan data yang digunakan adalah observasi, kuesioner serta wawancara. Metode analisis yang digunakan adalah statistik deskriptif dan analisis regresi linear berganda. Hasil penelitian menunjukkan bahwa 1) Motivasi berpengaruh positif dan signifikan terhadap kinerja pegawai di Kantor Kementerian Agama Kabupaten Bulukumba. 2) Kompetensi berpengaruh positif dan signifikan terhadap kinerja pegawai di Kantor Kementerian Agama Kabupaten Bulukumba. 3) Kompensasi berpengaruh positif dan signifikan terhadap kinerja pegawai di Kantor Kementerian Agama Kabupaten Bulukumba.
\end{abstract}

Kata Kunci: Motivasi kerja, kompetensi, kompensasi dan kinerja pegawai.

\section{Pendahuluan}

Tercapainya tujuan organisasi hanya dimungkinkan karena upaya para pelaku yang terdapat pada organisasi tersebut. Dalam hal ini sebenarnya terdapat hubungan yang erat antara kinerja perorangan dengan kinerja organisasi. Dengan perkataan lain bila kinerja pegawai baik maka kemungkinan besar kinerja organisasi juga akan baik. Sukses tidaknya seorang pegawai dalam bekerja akan dapat diketahui apabila organisasi yang bersangkutan menerapkan sistem penilaian kinerja (Gani, 2020; Tara, 2015). Kinerja adalah hasil kerja yang dapat dicapai oleh seseorang atau sekelompok orang dalam suatu organisasi, sesuai dengan wewenang dan tanggung jawab masing-masing dalam rangka upaya mencapai tujuan organisasi yang bersangkutan secara legal, tidak melanggar hukum dan sesuai dengan moral maupun etika. Jadi kinerja merupakan hal yang penting bagi organisasi serta dari pihak pegawai itu sendiri. Kinerja pegawai dipengaruhi oleh beberapa faktor baik yang berhubungan dengan tenaga kerja itu sendiri maupun yang berhubungan dengan organisasi (Dhermawan et al., 2012). Dalam usaha pencapaian tujuan organisasi yang telah ditetapkan sebelumnya, tugas pemimpinlah untuk memberdayakan semua sumber-sumber yang ada dalam organisasi terutama sumber daya manusianya melalui pemberian motivasi. Motivasi yang paling baik adalah motivasi yang muncul dari dalam diri pribadi pegawai tersebut, sehingga para pegawai akan memberikan yang terbaik dari dirinya demi kemajuan organisasinya. Tercapainya kepuasan kerja pegawai tidak semata-mata disebabkan oleh gaji, fasilitas kerja yang cukup, akan tetapi dapat pula oleh hal-hal lain yang bisa menambah semangat atau gairah kerja pegawai. Menurut Pratama (2015) kompensasi juga berpengaruh terhadap kinerja pegawai karena konstribusi yang diberikan pegawai kepada organisasi harus diimbangi dengan kompensasi yang cukup dan layak, karena apabila dirasa kompensasi yang diberikan kurang sesuai tentu akan berpengaruh dengan kinerja pegawai. Tujuan utama organisasi merancang sistem kompensasi adalah untuk memotivasi karyawan dalam meningkatkan kinerjanya serta mempertahankan karyawan yang berkompeten. Oleh karena itu perhatian organisasi terhadap pengaturan kompensasi secara rasional dan adil sangat diperlukan. Kompetensi juga berpengaruh terhadap kinerja, karena kompetensi yang 
dimiliki oleh pegawai diharapkan menjadi perilaku kunci yang dibutuhkan untuk melaksanakan peran tertentu untuk menghasilkan prestasi kerja yang memuaskan sehingga dapat memberikan dampak positif terhadap peningkatan kinerja dan kualitas pelayanan yang diberikan pegawai kepada masyarakat yang pada akhirnya akan mengarah pada pencapaian tujuan organisasi yang telah ditetapkan. Semakin baik kompetensi pegawai maka diharapkan semakin baik pula kinerjanya (Dhermawan et al., 2012). Sumber Daya Manusia (SDM) berbasis kompetensi dilakukan agar dapat memberikan hasil yang sesuai dengan tujuan dan sasaran organisasi dengan standar kinerja yang telah ditetapkan. Menurut (Barba-Aragón \& Jiménez-Jiménez, 2020) kompetensi adalah suatu kemampuan untuk melaksanakan suatu pekerjaan yang dilandasi atas keterampilan dan pengetahuan serta didukung oleh sikap kerja yang dituntut oleh pekerjaan tersebut. Kompetensi yang dimiliki oleh pegawai secara individual harus mampu mendukung pelaksanaan strategi organisasi dan mampu mendukung setiap perubahan yang dilakukan manajemen.

Berdasarkan landasan teori diatas, fenomena yang terjadi di lapangan sesuai hasil pengamatan penulis dan survei awal menunjukkan bahwa pada kenyataannya kinerja pegawai di Kementrian Agama Kabupaten Bulukumba belum sesuai dengan standar yang diharapkan, adanya aktivitas yang tidak produktif yang dilakukan oleh para pegawai di jam-jam kerja, ada kesan bahwa pegawai hanya datang, duduk diam dan pulang, melakukan aktifitas yang tidak sesuai dengan tupoksinya, banyak pegawai yang datang tidak tepat waktu dan pulang sebelum jam pulang dan tidak tau apa yang harus dikerjakan. Berdasarkan hasil wawancara awal pada salah satu pejabat di Kementrian Agama Kabupaten Bulukumba diketahui bahwa kinerja pegawai masih rendah. Hal ini ditunjukkan dengan banyaknya pekerjaan yang tidak selesai tepat pada waktunya, sikap pegawai yang kurang ramah terhadap pengunjung, dan pegawai kurang cepat dan cekatan dalam melayani permintaan tamu. Motivasi merupakan salah faktor yang menyebabkan menurunnya kinerja pegawai pada Kementrian Agama Kabupaten Bulukumba dalam bekerja karena ada beberapa pegawai yang merasa kurang puas dengan pemenuhan kebutuhan fisiknya. Misalnya pemberian fasilitas, tunjangan-tunjangan dan lainlain yang menyebabkan pegawai kurang termotivasi dalam bekerja. Hal ini tampak sebagian pegawai merasa tidak mendapat tunjangan yang cukup serta kehangatan hubungan kerja dengan atasan maupun sesama rekan kerja. Setiap pimpinan maupun manajer dalam organisasi perlu menyadari pentingnya memelihara serta meningkatkan kinerja para pegawai dengan memberikan teknik-teknik motivasi yang tepat dan sesuai dengan kebutuhan mereka. Berdasarkan wawancara terhadap beberapa pegawai, diindikasikan terjadi penurunan kinerja pegawai yang terjadi karena kurangnya kompensasi yang mereka terima. Kompensasi yang diterima antar karyawan berbeda-beda tergantung pada jabatan dan lamanya bekerja. Pegawai merasa pekerjaannya tidak dihargai oleh atasan. Hasil wawancara dengan dua orang staf pelayanan mengatakan bahwa kompensasi yang mereka terima tidak mencukupi. Honor yang mereka terima tidak tepat waktu diberikan oleh Instansi. Dan ini membuat motivasi untuk bekerja mereka berkurang. Berdasarkan hasi wawancara pada salah satu pegawai di Kementrian Agama Kabupaten Bulukumba bahwa ada beberapa pegawai yang tidak begitu paham mengenai penggunaan teknologi informasi terkhusus pegawai yang sudah tua. Banyaknya pekerjaan yang tidak terselesaikan tepat waktu karena di era globalisasi ini sebagian besar pekerjaan menggunakan teknologi informasi.

Tabel 1. Rumusan dan Tujuan Penelitian

\begin{tabular}{|c|c|}
\hline Rumusan Masalah & Tujuan Penelitian \\
\hline $\begin{array}{l}\text { 1. Apakah Motivasi Kerja berpengaruh terhadap } \\
\text { Kinerja Pegawai Kementrian Agama Kabupaten } \\
\text { Bulukumba? }\end{array}$ & $\begin{array}{l}\text { 1. Mengetahui pengaruh motivasi kerja terhadap } \\
\text { Kinerja Pegawai Kementrian Agama } \\
\text { Kabupaten Bulukumba }\end{array}$ \\
\hline $\begin{array}{l}\text { 2. Apakah Kompetensi berpengaruh terhadap } \\
\text { Kinerja Pegawai Kementrian Agama Kabupaten } \\
\text { Bulukumba? }\end{array}$ & $\begin{array}{l}\text { Mengetahui pengaruh kompetensi terhadap } \\
\text { Kinerja Pegawai Kementrian Agama } \\
\text { Kabupaten Bulukumba }\end{array}$ \\
\hline $\begin{array}{l}\text { Apakah Kompensasi berpengaruh terhadap } \\
\text { Kinerja Pegawai Kementrian Agama Kabupaten } \\
\text { Bulukumba? }\end{array}$ & $\begin{array}{l}\text { Mengetahui pengaruh kompensasi terhadap } \\
\text { Kinerja Pegawai Kementrian Agama } \\
\text { Kabupaten Bulukumba }\end{array}$ \\
\hline
\end{tabular}

\section{Tinjauan Pustaka}




\section{A. Motivasi Kerja}

Manusia sebagai salah satu komponen dasar didalam organisasi publik harus memiliki motivasi yang tersimpan didalam hati atau keinginannya yang dapat memacu untuk meraih apa yang dicitacitakan. Motivasi adalah konsep yang menguraikan tentang kekuatan-kekuatan yang ada dalam diri karyawan yang memulai dan dapat mengarahkan perilaku orang tersebut (Cahyani et al., 2015; Wahyuni, 2008). Motivasi kerja adalah dorongan, upaya dan keinginan yang ada dalam diri manusia yang mengaktifkan, memberi daya serta mengarahkan perilaku dalam pelaksanaan tugas di lingkungan pekerjaannya. Hakikat dari motivasi kerja adalah dorongan untuk melakukan segala sesuatu yang lebih baik dari yang lainnya dalam melakukan kegiatan untuk mencapai tujuan. Motivasi merupakan hasrat di dalam diri seseorang yang menyebabkan orang tersebut melakukan tindakan. Motivasi adalah serangkaian sikap dan nilai-nilai yang mempengaruhi individu untuk mencapai hasil yang spesifik sesuai dengan tujuan individu. Motivasi adalah kesediaan melakukan usaha tingkat tinggi guna mencapai sasaran organisasi yang dikondisikan oleh kemampuan usaha tersebut memuaskan kebutuhan sejumlah individu. Motivasi adalah sebagai pemberi daya gerak yang menciptakan kegairahan kerja seseorang, agar mereka mau bekerja sama, bekerja efektif dan terintegrasi dengan segala daya upaya untuk mencapai kepuasan. Motivasi merupakan faktor yang mendorong orang untuk bertindak dengan cara tertentu. Dengan bertitik tolak dari arti motivasi tersebut, motivasi kerja adalah sesuatu yang menimbulkan dorongan atau semangat kerja. Dengan kata lain, motivasi kerja adalah pendorong semangat kerja. Berdasarkan pengertian di atas dapat disimpulkan bahwa motivasi kerja merupakan kegiatan yang mengakibatkan, menyalurkan, memelihara, dan mendorong perilaku seseorang untuk melakukan suatu perbuatan atau tindakan tertentu secara optimal untuk mencapai apa yang menjadi sasaran organisasi (Syafitri Sitorus et al, 2021; Yoel Brando Sitopu, et al, 2021; Mulang, 2021; Basalamah \& As'ad, 2021).

Teori motivasi pada dasarnya dibedakan menjadi dua, yaitu teori motivasi kepuasan dan teori motivasi proses, yaitu: (a) Teori Motivasi Kepuasan, teori ini mendasarkan pada faktor-faktor kebutuhan dan kepuasan individu sehingga msereka mau melakukan aktivitasnya, jadi mengacu pada diri seseorang. Teori ini mencoba mencari tahu tentang kebutuhan apa yang dapat memuaskan dan yang dapat mendorong semangat kerja. Hieraki Teori Kebutuhan, teori motivasi yang sangat terkenal adalah teori kebutuhan yang dikemukakan oleh Abraham Maslow (Maslow, 1954). Menurut Maslow bahwa pada setiap diri manusia itu sendiri terdiri atas lima kebutuhan yaitu: kebutuhan fisiologis, Kebutuhan rasa aman, kebutuhan sosial, kebutuhan penghargaan diri, kebutuhan untuk mengaktualisasikan diri, yaitu kebutuhan untuk menggunakan kemampuan, dan potensi. Teori Keadilan (Equity Theory), teori keadilan membantu memahami bagaimana seseorang pegawai mencapai kesimpulan bahwa ia diperlakukan adil atau tidak adil. Perasaan bahwa ia diperlakukan adil atau tidak adil merupakan pemikiran subyektif yang ia dapatkan (Haerani et al., 2020). Indikator motivasi kerja terdiri atas: Arah perilaku, Tingkat usaha, Tingkat kegigihan.

\section{B. Kompetensi}

Kompetensi menurut Guan et al (2016) dapat didefinisikan sebagai karakteristik yang mendasari seseorang berkaitan dengan efektifitas kinerja individu dalam pekerjaannya. Kompetensi dapat diartikan sebagai perilaku, pengetahuan, keterampilan, dan motivasi yang berperan besar dalam kesuksesan melaksanakan suatu pekerjaan. Kompetensi juga dapat diartikan sebagai tindakan cerdas, penuh tanggung jawab yang dimiliki seseorang sebagai syarat untuk dianggap mampu oleh masyarakat dalam melaksanakan tugas- tugas dibidang pekerjaan tertentu. Dalam Islam, kompetensi merupakan kemampuan yang penting yang harus dimiliki oleh sumber daya manusia, sebab jika sesuatu jabatan diserahkan bukan kepada ahlinya, hal tersebut justru akan berdampak buruk bagi perusahaan. Sebagaimana sabda Rasulullah dalam satu hadist yang diriwayatkan oleh Imam Bukhari dan Abu Hurairah. Rasulullah bersabda: "Ketika engkau menyia-nyiakan amanah, maka tunggulah kehancuran. Dikatakan, hai Rasulullah, apa yang membuatnya sia-sia? Rasul berkata : "Ketika suatu perkara diserahkan kepada yang bukan ahlinya, maka tunggulah kehancuran". Jadi pada prinsipnya kompetensi yang dimiliki oleh karyawan harus sesuai dengan keahlian/ spesialisasinya agar karyawan melaksanakan pekerjaan dalam suatu jabatan efektif dan efisien. Karakteristik kompetensi menurut Spencer \& Spencer (2008) terdiri dari 5 (Lima) karakteristik yaitu : Motives adalah sesuatu dimana 
sesorang secara konsisten berfikir sehingga ia melakukan tindakan. Traits (sifat), adalah watak yang membuat orang untuk berperilaku atau bagaimana seseorang merespon sesuatu dengan cara tertentu. Self Concept (konsep diri), adalah sikap dan nilai yang dimiliki seseorang. Knowledge (Pengetahuan), adalah informasi yang dimiliki seseorang untuk bidang tertentu. Pengetahuan merupakan kompetensi yang kompleks. Skills (keterampilan), adalah kemampuan untuk melaksanakan suatu tugas tertentu baik secara fisik maupun mental. Dengan mengetahui tingkat kompetensi maka perencanaan sumber daya manusia akan lebih baik hasilnya. Setiap organisasi pasti mengharapkan dan berupaya sekuat tenaga untuk dapat mencapai tujuan kinerja yang ditetapkan sebelumnya. Meskipun banyak faktor yang dapat mempengaruhi keberhasilan maupun kegagalannya mencapai tujuan tersebut, namun untuk sebagian besar ditentukan oleh kompetensi sumber daya manusia yang terdapat didalamnya. Baik sebagai pekerja bawah, menengah, maupun yang menduduki jabatan pemimpin (Dwi Riyanti et al., 2016). Berdasarkan pendapat-pendapat diatas dapat dijelaskan bahwa terdapat bermacam-macam jenis komptensi, yaitu: Kompetensi intelektual, kompetensi intelektual, kompetensi kognitif, kompetensi ini menunjukkan kapabilitas berkaitan dengan aplikasi pengetahuan dalam pemecahan masalah. Kompetensi kognitif sangat relevan dengan pekerjaan, karna menyangkut pekerjaan yang melibatkan penggunaan informasi untuk membuat keputusan dan pemecahan masalah. Kompetensi Emosional, kompetensi ini lebih pada kemampuan seseorang dalam mengendalikan diri, sehingga ketika terjadi masalah tidak akan menggangu kinerjanya maupun orang lain yang ada disekitarnya, dengan demikian orang tersebut dapat mengendalikan emosinya (Setiawan \& Latrini, 2016).

\section{Kompensasi}

Pada dasarnya manusia bekerja juga ingin memperoleh uang untuk memenuhi kebutuhan hidupnya. Untuk itulah seorang karyawan mulai menghargai kerja keras dan semakin menunjukkan loyalitas terhadap perusahaan dan karena itulah perusahaan memberikan penghargaan terhadap prestasi kerja karyawan yaitu dengan jalan memberikan kompensasi. Salah satu cara manajemen untuk meningkatkan prestasi kerja, memotivasi dan meningkatkan kinerja para karyawan adalah melalui kompensasi. Kompensasi penting bagi karyawan sebagai individu karena besarnya kompensasi mencerminkan ukuran karya mereka diantara para karyawan itu sendiri, keluarga dan masyarakat. Kompensasi acapkali juga disebut penghargaan dan dapat didefinisikan sebagai setiap bentuk penghargaan yang diberikan kepada karyawan sebagai balas jasa atas kontribusi yang mereka berikan kepada organisasi (Stone et al., 2015). Selain itu, terdapat beberapa pengertian kompensasi dari beberapa tokoh yaitu: kompensasi adalah apa yang seorang pekerja terima sebagai balasan dari pekerjaan yang diberikannya. Pemberian kompensasi merupakan salah satu pelaksanaan fungsi MSDM yang berhubungan dengan semua jenis pemberian penghargaan individual sebagai pertukaran dalam melaksanakan tugas keorganisasian. Kompensasi atau balas jasa bertujuan umumnya untuk kepentingan perusahaan dan karyawan. Kepentingan perusahaan dengan pemberian kompensasi yaitu memperoleh imbalan prestasi kerja yang lebih besar dari karyawan. Sedangkan kepentingan karyawan atas kompensasi yang diterima yaitu dapat memenuhi kebutuhan dan keinginan dan menjadi keamanan ekonomi rumah tangganya . Jadi dapat disimpulkan bahwa kompensasi adalah segala suatu yang diterima oleh para pegawai, baik uang, barang atau sebagainya sebagai balas jasa dari hasil kerja mereka pada organisasi. Kompensasi juga menjadi alasan utama mengapa kebanyakan orang bekerja pada perusahaan, karena dengan kompensasi tersebut para karyawan dapat memenuhi dan meningkatkan kebutuhan hidup mereka. Mengingat pentingnya faktor tenaga kerja dalam suatu organisasi maka, organisasi perlu memberikan perhatian khusus terhadap karyawannya agar lebih bersemangat dalam menjalankan tugas-tugasnya di perusahaan tersebut, karena dengan cara pemberian kompensasi yang layak dan adil akan lebih memacu motivasi kerja mereka.

Kompensasi mempunyai tiga komponen sebagai berikut : pembayaran uang secara langsung (direct financial payment). Pembayaran tidak langsung (indirect payment) dalam bentuk tunjangan dan asuransi. Ganjaran non finansial (non financial rewards) (Alam, Aida \& Muchtar, 2021). Kompensasi Langsung adalah kompensasi yang langsung dirasakan oleh penerimanya, yakni berupa gaji, upah, insentif merupakan hak karyawan dan kewajiban perusahaan untuk membayarnya. Kompensasi Tidak Langsung adalah kompensasi yang tidak dapat dirasakan secara langsung oleh karyawan, yakni benefit dan services (tunjangan pelayanan). Benefit dan services adalah kompensasi tambahan (financial atau non financial) yang diberikan berdasarkan kebijaksanaan perusahaan terhadap semua karyawan dalam 
usaha meningkatkan kesejahteraan mereka. Seperti tunjangan hari raya, uang pensiun, pakaian dinas, olah raga dan darma wisata (family gathering). Kompensasi merupakan hal yang penting, yang merupakan dorongan atau motivasi utama seseorang karyawan untuk bekerja. Hal ini berarti bahwa karyawan menggunakan pengetahuan, keterampilan, tenaga dan waktu bukan semata-mata ingin mengabdikan diri pada perusahaan, tetapi ada tujuan lain yaitu mengharapkan imbalan atau balas jasa atas hasil yang telah diberikan. Selain itu, kompensasi yang diberikan kepada karyawan juga berpengaruh pada kondisi kerja karyawan tersebut. Kompensasi adalah segala sesuatu yang diterima oleh karyawan sebagai balas jasa untuk kerja atau pengabdian mereka. Pemberian kompensasi kepada karyawan harus mempunyai dasar yang logis dan rasional. Kompensasi sangat penting bagi karyawan itu sendiri sebagai individu, karena besarnya kompensasi merupakan pencerminan atau ukuran nilai pekerjaan karyawan itu sendiri. Kompensasi bukan hanya penting untuk para karyawan saja, melainkan juga penting bagi organisasi itu sendiri, karena program-program kompensasi adalah merupakan pencerminan upaya organisasi untuk mempertahankan sumber daya manusia. Bila organisasi tidak memperhatikan dengan baik tentang kompensasi bagi karyawannya, tidak mustahil organisasi itu lambat laun akan kehilangan sumber daya manusia yang berkualitas tinggi. Hal ini berarti harus mengeluarkan biaya lagi untuk mencari tenaga baru, atau melatih tenaga yang sudah ada untuk menggantikan karyawan yang keluar (Akob et al., 2020).

\section{Kinerja Pegawai}

Kinerja memiliki pengertian yang beragam dari berbagai pakar, tetapi tetap memiliki kesamaan secara umum. Kinerja adalah tingkat pencapaian hasil atas pelaksanaan tugas tertentu. Kinerja perusahaan adalah tingkat pencapaian hasil dalam rangka mewujudkan tujuan perusahaan. Informasi tentang kinerja organisasi merupakan suatu hal yang sangat penting digunakan untuk mengevaluasi apakah proses kinerja yang dilakukan organisasi selama ini sudah sejalan dengan tujuan yang diharapkan atau belum. Akan tetapi dalam kenyataannya banyak organisasi yang justru kurang atau bahkan tidak jarang ada yang mempunyai informasi tentang kinerja dalam organisasinya. Kinerja sebagai hasil-hasil fungsi pekerjaan/kegiatan seseorang atau kelompok dalam suatu organisai yang dipengaruhi oleh berbagai faktor untuk mencapai tujuan organisasi dalam periode waktu tertentu. Performance atau Kinerja adalah hasil kerja yang dapat dicapai oleh seseorang atau kelompok orang dalam suatu organisasi sesuai dengan wewenang dan tanggungjawabnya masing-masing dalam upaya pencapaian tujuan organisasi (M., 2016; Mahmoud et al., 2017). Kinerja adalah kesediaan seseorang atau kelompok orang untuk melakukan sesuatu kegiatan dan menyempurnakannya sesuai dengan tanggung jawabnya dengan hasil seperti yang diharapkan. Kinerja atau prestasi kerja adalah suatu hasil kerja yang dicapai seseorang dalam melaksanakan tugas-tugas yang dibebankan kepadanya yang didasarkan atas kecakapan, pengalaman, dan kesungguhan, serta waktu. Kinerja secara umum merupakan wajah dan citra pegawai yang tercermin dari suatu organisasi, tetapi didalam pengaplikasian secara benar tidaklah mudah, disebabkan sifat manusia yang terdiri dari berbagai macam karakteristik dan memiliki perasaan, watak dan kemampuan yang berbeda-beda pengertian (Chuang \& Lin, 2013; Dong \& Phuong, 2018).

\section{E. Kerangka Konseptual}

Dari masalah yang dihadapi oleh Departemen Agama Kabupaten Bulukumba dan didukung oleh kajian teori dari hasil penelitian terdahulu, maka disusunlah kerangka pemikiran bahwa Kinerja $(\mathrm{Y})$ Pegawai Departemen Agama Kabupaten Bulukumba dipengaruhi oleh variabel, motivasi kerja (X1), kompetensi (X2), dan kompensasi (X3). Hubungan kausalitas ini Secara umum disajikan pada gambar di bawah ini:

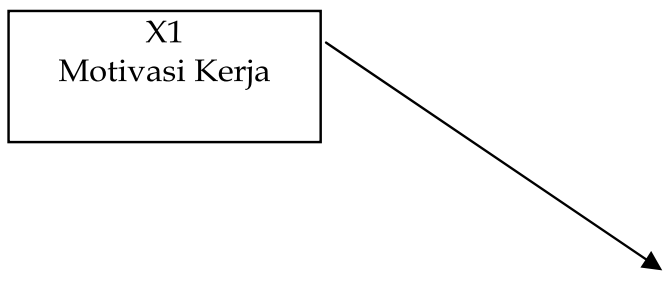




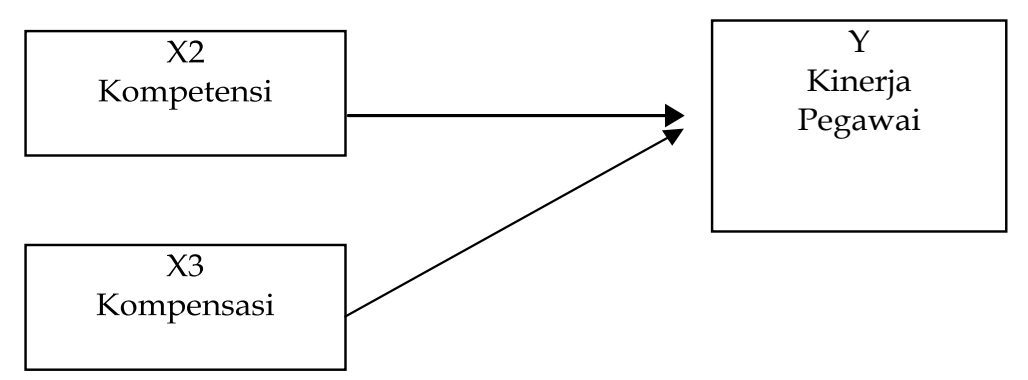

Gambar 1. Kerangka Konseptual

Berdasarkan kerangka pemikiran penelitian, maka dirumuskan hipotesis kerja sebagai berikut :

1. Diduga Motivasi Kerja berpengaruh signifikan terhadap Kinerja Pegawai Kementrian Agama Kabupaten Bulukumba

2. Diduga Kompetensi berpengaruh signifikan terhadap Kinerja Pegawai Kementrian Agama Kabupaten Bulukumba

3. Diduga Kompensasi berpengaruh signifikan terhadap Kinerja Pegawai Kementrian Agama Kabupaten Bulukumba

\section{Metode Penelitian}

Jenis penelitian yang digunakan dalam penelitian ini adalah penelitian explanatory. Penelitian explanatory adalah penelitian yang bersifat penjelasan di mana penelitian ini menyoroti hubungan antara variabel-variabel independen terhadap variabel dependen dan menguji hipotesis yang telah dirumuskan sebelumnya. Lokasi penelitian mengenai pengaruh Motivasi, Kompetensi dan Kompensasi terhadap Kinerja Pegawai ini dilaksanakan di Kementrian Agama Kabupaten Bulukumba yang beralamatkan di jalan Jl Kenari No, 17 Bulukumba. Sedangkan waktu yang digunakan untuk penyelesaian proses penelitian berlangsung selama kurang lebi 3 bulan, yang dimulai bulan Januari 2021 sampai dengan bulan Maret 2021. Data yang digunakan dalam penelitian ini adalah data primer dan data sekunder. Data primer diperoleh dari penyebaran kuesioner kepada pegawaiKantorKementrian Agama Kota Makassar. Sedang data sekunder bersumber dari penelitian terdahulu dan dokumentasi lainnya yang relevan. Dalam penelitian ini teknik yang digunakan untuk mengumpulkan data adalah sebagai berikut : (1) Metode Kuesioner (angket), yaitu pengumpulan data dengan cara subyek yang diteliti mengisi angket yang telah disediakan oleh peneliti. Dalam penelitian ini instrumen pengumpulan datanya menggunakan konsep skala sikap Likert. Model ini dikembangkan oleh Rensis Likert, pada model ini lebih banyak digunakan untuk penelitian psikologi (moral), sikap dan lain sebagainya. Pada skala Likert ini responden akan menjawab pernyataanpernyataan yang sudah dibuat oleh peneliti dengan memberikan tanda silang. Dari jawaban responden kemudian diberikan skor nilai. Pemberian bobot atau skor disusun dengan bertingkat yang konsisten. Dalam penelitian ini terdapat 5 tipe point jawaban yang diberikan. Penilaian diukur scoring berdasarkan skala Likert.

Tabel.2. Skala Likert

\begin{tabular}{|c|c|}
\hline Jawaban & Skor \\
\hline Sangat Setuju & 5 \\
\hline Setuju & 4 \\
\hline Kurang Setuju & 3 \\
\hline Tidak Setuju & 2 \\
\hline Sangat Tidak Setuju & 1 \\
\hline
\end{tabular}

Populasi dalam penelitian ini adalah seluruh pegawai Kementrian Agama Kabupaten Bulukumba sebanyak 55 orang. Berdasarkan penelitian ini karena jumlah populasinya tidak lebih besar dari 100 orang responden, maka penulis mengambil 100\% jumlah populasi yang ada pada Kementrian Agama Kabupaten Bulukumba yaitu sebanyak 55 orang responden. Dengan demikian penggunaan seluruh populasi tanpa harus menarik sampel penelitian sebagai unit observasi disebut sebagai metode sensus. 
Metode analisis data, pengumpulan data primer dilakukan dengan cara survei menggunkan kuesioner tertutup. Skala pengukuran yang digunakan untuk penilaian kuesioner adalah skala Likert. Uji Kualitas Data dilakukan dengan Uji validitas dan uji reabilitas. Uji validitas digunakan untuk mengetahui valid atau tidaknya suatu kuesioner. Suatu kuesioner dikatakan valid jika pertanyaan pada kuesioner mampu mengungkapkan sesuatu yang akan diukur oleh kuesioner tersebut (Sugiyono, 2011). Uji validitas dilakukan dengan membandingkan nilai r-hitung dengan nilai r-tabel dengan degree of freedom $(\mathrm{df})=\mathrm{n}-2$ dengan alpha 0,05 . Uji reliabilitas adalah alat untuk mengukur suatu kuesioner yang merupakan indikator dari variabel atau konstruk. Suatu kuesioner dikatakan reliable atau handal jika jawaban seseorang terhadap pertanyaan adalah konsisten atau stabil dari waktu ke waktu (Hair et al., 2014). Suatu konstruk atau variable dikatakan reliable jika memberikan nilai Cronbach Alpha >0,70.

Uji Asumsi Klasik, sebelum dilakukan pengujian hipotesis yang menggunakan analisis regresi linear berganda maka diperlukan pengujian asumsi klasik meliputi: Uji Normalitas, Uji Multikolinieritas. Untuk mendeteksi ada atau tidaknya multikolinearitas di dalam model regresi dapat dilihat dari nilai tolerance dan Variance Inflation Factor (VIF). Kedua ukuran ini menunjukan setiap variable independen manakah yang dijelaskan oleh variabel independen lainnya. Tolerance mengukur variabel independen yang terpilih yang tidak dijelaskan oleh variabel independen lainnya. Jadi, nilai tolerance yang rendah sama dengan nilai VIF tinggi (arena VIF $=1 /$ tolerance). Pengujian Hipotesis terdiri dari: Uji Signifikansi Parameter Individual (Uji-t), Uji-t pada dasarnya menunjukan seberapa jauh suatu variabel independen secara individual dalam menerangkan variasi-variasi variabel dependen. Jika nilai probability-t lebih besar dari 0,05 maka tidak ada pengaruh dari variabel independen terhadap varibel dependen (koefisien regresi tidak signifikan) sedangkan jika nilai probability-t lebih kecil dari 0,05 maka terdapat pengaruh dari variabel independen terhadap variabel dependen (koefisien regresi signifikan). Uji Signifikansi Simultan (Uji-F), Uji statistik-F menunjukkan apakah semua variabel independen atau bebas yang dimasukkan dalam model mempunyai pengaruh secara bersama-sama terhadap variabel dependen atau terikat untuk mengambil keputusan hipotesis diterima atau ditolak dengan membandingkan tingkat signifikansi (alpha) sebesar 5\% $(0,05)$. Dalam penelitian ini pengujian hipotesis secara simultan dimaksudkan untuk mengukur besarnya pengaruh Motivasi (X1), Kompetensi (X2), Kompensasi (X3), terhadap kinerja pegawai (Y). (3) Analisis Linear Berganda, regresi Linear berganda digunakan untuk megetahui seberapa besar pengaruh variabel bebas dari penelitian ini yaitu: Motivasi Kerja, Kompetensi, dan Kompensasi terhadap variabel terikatnya yaitu Kinerja Pegawai. Persamaan umum regresi linear berganda adalah sebagai berikut:

Dimana:

$$
\mathrm{Y}=\mathrm{a}+\mathrm{b} 1 \mathrm{X} 1+\mathrm{b} 2 \mathrm{X} 2+\mathrm{b} 3 \mathrm{X} 3+\mathrm{e}
$$

$\begin{array}{lll}\mathrm{Y} & = & \text { Kinerja Pegawai } \\ \mathrm{X} 1 & = & \text { variabel Motivasi Kerja } \\ \mathrm{X} 2 & = & \text { variabel Kompetensi } \\ \mathrm{X} 3 & = & \text { variabel Kompensasi } \\ \mathrm{a} & = & \text { konstanta } \\ \mathrm{b} 1, \mathrm{~b} 2, \mathrm{~b} 3 & = & \text { koefisien garis regresi } \\ \mathrm{e} & = & \text { error }\end{array}$

\section{Hasil dan Pembahasan}

\section{A. Karakteristik Responden}

Untuk mengetahui variasi sikap dan perilaku pegawai Kantor Kementerian Agama Kabupaten Bulukumba, maka perlu terlebih dahulu dikemukakan identitas pegawai sebagai responden yang diharapkan dapat memperkuat kedudukan dan posisi pada penelitian ini. Berdasarkan hasil penelitian yang dilakukan terhadap 55 orang responden, maka dapat diketahui gambaran karasteristik responden tentang jenis kelamin, umur, tingkat pendidikan dan masa kerja.

\section{a) Jenis Kelamin}


Berdasarkan jenis kelamin, responden penelitian dapat dikelompokkan sebagaimana pada tabel berikut :

Tabel 3. Karakteristik responden berdasarkan jenis kelamin

\begin{tabular}{|c|c|c|}
\hline Jenis Kelamin & Jumlah (orang) & Persentase (\%) \\
\hline Laki-laki & 24 & 43,63 \\
\hline Perempuan & 31 & 56,37 \\
\hline Jumlah & 55 & 100 \\
\hline
\end{tabular}

Berdasarkan Tabel 3 dapat diketahui bahwa jumlah responden berdasarkan jenis kelamin paling banyak adalah perempuan sebanyak 31 orang dengan persentase $56,37 \%$, kemudian laki-laki sebanyak 24 orang dengan persentase 43,63\%. Hal ini menunjukkan bahwa sebagian besar pegawai Kantor Kementerian Agama Kabupaten Bulukumba adalah perempuan, dimana diharapkan bahwa pegawai perempuan dapat berkinerja dengan baik dengan memberikan pelayanan maksimal kepada masyarakat khususnya kepada masyarakat dalam lingkup Kantor Kementerian Agama Kabupaten Bulukumba.

\section{b) Umur Pegawai}

Berdasarkan umur, responden penelitian dapat dikelompokkan sebagaimana pada tabel berikut :

Tabel 4. Karakteristik responden berdasarkan umur

\begin{tabular}{|c|c|c|}
\hline Umur (Tahun) & Jumlah (orang) & Persentase (\%) \\
\hline $20-29$ & 5 & 9,10 \\
\hline $30-39$ & 10 & 18,18 \\
\hline $40-49$ & 26 & 47,27 \\
\hline $50-59$ & 14 & 25,45 \\
\hline Jumlah & 55 & 100 \\
\hline
\end{tabular}

Berdasarkan Tabel 4 dapat diketahui bahwa jumlah responden berdasarkan umur paling banyak adalah usia $40-49$ tahun sebanyak 26 orang dengan persentase $47,27 \%$, diikuti usia $50-59$ tahun sebanyak 14 orang dengan persentase $25,45 \%$, diikuti usia 30-39 tahun sebanyak 10 orang dengan persentase 18,18\%, dan usia 20 - 29 tahun sebayak 5 orang dengan persentase 9,10\%. Hal ini menunjukkan bahwa sebagian besar responden memiliki usia yang terbilang kurang produktif lagi yaitu usia 40 - 49 tahun sehingga dalam pencapaian kinerja mungkin kurang optimal lagi.

\section{c) Tingkat Pendidikan}

Berdasarkan tingkat pendidikan, responden penelitian dapat dikelompokkan sebagaimana pada tabel berikut :

Tabel 5. Karakteristik responden berdasarkan tingkat pendidikan

\begin{tabular}{|c|c|c|}
\hline Pendidkan & Jumlah (orang) & Persentase (\%) \\
\hline Strata 1 (S1) & 36 & 65,46 \\
\hline Strata 2 (S2) & 19 & 34,54 \\
\hline Jumlah & 55 & 100 \\
\hline
\end{tabular}

Berdasarkan Tabel 5 dapat diketahui bahwa jumlah responden berdasarkan tingkat pendidikan paling banyak adalah responden pada kelompok pendidikan Strata satu (S1) sebanyak 36 orang dengan persentase sebesar 65,46 \%, dan kelompok pendidikan Strata dua (S2) sebanyak 19 orang dengan persentase sebesar $34,54 \%$. Hal ini menunjukkan bahwa pegawai dengan tingkat pendidikan Strata satu (S1) secara umum memiliki kesesuaian dengan jenis pekerjaan yang diterimanya dengan kemampuan intelektual yang dimilikinya maka logika berpikirnya akan semakin baik dan didukung dengan wawasan yang luas sehingga akan memudahkan pegawai tersebut untuk bekerja sesuai dengan latar belakang pendidikannya.

\section{d) Masa Kerja}

Berdasarkan masa kerja, responden penelitian dapat dikelompokkan sebagaimana pada tabel berikut : 
Tabel 6. Deskripsi responden berdasarkan masa kerja

\begin{tabular}{|c|c|c|}
\hline Masa Kerja & Jumlah (orang) & Persentase (\%) \\
\hline $1-5$ tahun & 5 & 9,10 \\
\hline $6-10$ tahun & 10 & 18,18 \\
\hline $11-15$ tahun & 9 & 16,36 \\
\hline $16-20$ tahun & 12 & 21,81 \\
\hline$>21$ & 19 & 34,55 \\
\hline Jumlah & 55 & 100 \\
\hline
\end{tabular}

Berdasarkan Tabel 6 dapat diketahui bahwa jumlah responden berdasarkan masa kerja paling banyak adalah pegawai dengan kelompok masa kerja > 21 tahun sebanyak 19 orang dengan persentase sebesar 34,55 \%, diikuti pegawai dengan kelompok masa kerja 16-20 tahun sebanyak 12 orang dengan persentase sebesar 21,81 \%, kemudian pegawai dengan kelompok masa kerja 11-15 tahun sebanyak 9 orang dengan persentase sebesar 16,36 \%, dan pegawai dengan kelompok masa kerja 6-10 tahun sebanyak 10 orang dengan persentase $18,18 \%$, dan terakhir pegawai dengan kelompok masa kerja 1-5 tahun sebanyak 5 orang dengan persentase 9,10\%. Hal ini membuktikan bahwa masa kerja seseorang dalam suatu organisasi dapat menjadi tolak ukur loyalitas dalam bekerja serta menunjukkan masa baktinya.

\section{B. Deskripsi Variabel Penelitian}

Deskripsi variabel penelitian dapat digunakan untuk menjawab pertanyaan terkait dengan masing-masing variabel penelitian yang digunakan secara sendiri-sendiri. Penelitian ini menggunakan jumlah responden sebanyak 55 orang pegawai pada Kantor Kementerian Agama Kabupaten Bulukumba yang tersebar di berbagai bidang dengan tugas pokok dan fungsi yang berbeda-beda sesuai dengan bidangnya. Jumlah pegawai yang diteliti seluruhnya berjumlah 55 orang, yang terdiri dari lakilaki sebanyak 24 orang dan perempuan sebanyak 31 orang. Waktu pelaksanaan penelitian dilakukan selama tiga bulan yaitu Januari - Maret 2021, dengan menggunakan tehnik pengumpulan data yaitu menggunakan kuisioner dan wawancara kepada para pegawai dalam lingkup Kantor Kementerian Agama Kabupaten Bulukumba. Variabel penelitian ini terdiri dari Motivasi (X1), Kompetensi (X2) dan Kompensasi (X3) sebagai variabel bebas (independent variable) dan Kinerja (Y) sebagai variabel terikat (dependent variable). Adapun deksripsi dari variabel-variabel diuraikan sebagai berikut:

Tabel 7. Deskripsi jawaban responden terhadap variabel motivasi

\begin{tabular}{|c|c|c|c|c|c|c|c|c|c|c|c|}
\hline \multirow{3}{*}{ Indikator } & \multicolumn{11}{|c|}{ Frekuensi jawaban responden } \\
\hline & \multicolumn{2}{|c|}{ STS (1) } & \multicolumn{2}{|r|}{ TS (2) } & \multicolumn{2}{|r|}{ KS (3) } & \multicolumn{2}{|r|}{ S (4) } & \multicolumn{2}{|c|}{ SS (5) } & \multirow{2}{*}{ Mean } \\
\hline & $\bar{F}$ & $\%$ & $\mathrm{~F}$ & $\%$ & $\mathrm{~F}$ & $\%$ & $\bar{F}$ & $\%$ & $\bar{F}$ & $\%$ & \\
\hline $\begin{array}{l}\text { Kebutuhan } \\
\text { fisiologis }\end{array}$ & - & - & 2 & 3,64 & 33 & 60,00 & 20 & 36,36 & - & - & 3,33 \\
\hline $\begin{array}{l}\text { Kebutuhan } \\
\text { rasa aman }\end{array}$ & - & - & - & - & 35 & 63,64 & 20 & 36,36 & - & - & 3,36 \\
\hline $\begin{array}{l}\text { Kebutuhan } \\
\text { sosial }\end{array}$ & - & - & 3 & 5,46 & 43 & 78,18 & 9 & 16,36 & - & - & 3,11 \\
\hline $\begin{array}{l}\text { Kebutuhan } \\
\text { penghargaan }\end{array}$ & - & - & 1 & 1,82 & 38 & 69,09 & 16 & 29,09 & - & - & 3,27 \\
\hline $\begin{array}{l}\text { Aktualisasi } \\
\text { diri }\end{array}$ & - & - & 2 & 3,64 & 37 & 67,27 & 16 & 29,09 & - & - & 3,25 \\
\hline
\end{tabular}

Berdasarkan Tabel 7, dapat diketahui bahwa indikator yang paling dominan/besar dalam membentuk variabel motivasi pada Kantor Kementerian Agama Kabupaten Bulukumba adalah indikator kebutuhan rasa aman dengan nilai rata-rata 3,36, kemudian diikuti oleh indikator kebutuhan fisiologis dengan nilai rata-rata 3,33, indikator penghargaan dengan nilai rata-rata 3,27, indikator aktualisasi diri dengan nilai rata-rata 3,25. Indikator yang paling terkecil dalam membentuk variabel motivasi adalah indikator kebutuhan sosial dengan nilai rata-rata 3,11, sehingga indikator tersebut perlu ditingkatkan agar mampu mendukung dalam variabel motivasi guna meningkatkan kinerja pegawai. 
Tabel 8. Deskripsi Jawaban Responden Terhadap Variabel Kompetensi

\begin{tabular}{|c|c|c|c|c|c|c|c|c|c|c|c|}
\hline \multirow{3}{*}{ Indikator } & \multicolumn{11}{|c|}{ Frekuensi jawaban responden } \\
\hline & \multicolumn{2}{|c|}{ STS(1) } & \multicolumn{2}{|r|}{ TS (2) } & \multicolumn{2}{|c|}{$\mathrm{KS}(3)$} & \multicolumn{2}{|c|}{$\mathrm{S}(4)$} & \multicolumn{2}{|c|}{ SS (5) } & \multirow[t]{2}{*}{ Mean } \\
\hline & $\mathrm{F}$ & $\%$ & $\mathrm{~F}$ & $\%$ & $\mathrm{~F}$ & $\%$ & $\mathrm{~F}$ & $\%$ & $\mathrm{~F}$ & $\%$ & \\
\hline Pengetahuan & - & - & - & - & 20 & 36,36 & 35 & 63,64 & - & - & 3,64 \\
\hline Keterampilan & - & - & 1 & 1,82 & 36 & 65,45 & 18 & 32,73 & - & - & 3,31 \\
\hline Konsep diri & - & - & - & - & 36 & 65,45 & 19 & 34,55 & - & - & 3,34 \\
\hline $\begin{array}{l}\text { Karasteristik } \\
\text { pribadi }\end{array}$ & - & - & 1 & 1,82 & 24 & 43,64 & 30 & 54,54 & - & - & 3,53 \\
\hline Motif & - & - & 4 & 7,28 & 25 & 45,45 & 26 & 47,27 & - & - & 3,40 \\
\hline
\end{tabular}

Berdasarkan Tabel 8, dapat diketahui bahwa indikator yang paling dominan/besar dalam membentuk variabel kompetensi pada Kantor Kementerian Agama Kabupaten Bulukumba adalah indikator pengetahuan dengan nilai rata-rata 3,64, kemudian diikuti oleh indikator karasteristik pribadi dengan nilai rata-rata 3,53, indikator motif dengan nilai rata-rata 3,40, indikator konsep diri dengan nilai rata-rata 3,34. Indikator yang paling terkecil dalam membentuk variabel kompetensi adalah indikator keterampilan dengan nilai rata-rata 3,31, sehingga indikator tersebut perlu ditingkatkan agar mampu mendukung dalam variabel kompetensi guna meningkatkan kinerja pegawai.

Tabel 9. Deskripsi Jawaban Responden Terhadap Variabel Kompensasi

\begin{tabular}{|c|c|c|c|c|c|c|c|c|c|c|c|}
\hline \multirow{3}{*}{ Indikator } & \multicolumn{11}{|c|}{ Frekuensi jawaban responden } \\
\hline & \multicolumn{2}{|c|}{ STS (1) } & \multicolumn{2}{|c|}{ TS (2) } & \multicolumn{2}{|c|}{$\mathrm{CS}(3)$} & \multicolumn{2}{|c|}{$\mathrm{S}(4)$} & \multicolumn{2}{|c|}{ SS (5) } & \multirow{2}{*}{ Mean } \\
\hline & $\mathrm{F}$ & $\%$ & F & $\%$ & $\mathrm{~F}$ & $\%$ & $\mathrm{~F}$ & $\%$ & $\mathrm{~F}$ & $\%$ & \\
\hline Gaji & 2 & 3,64 & 1 & 1,82 & 35 & 63,64 & 17 & 30,90 & - & - & 3,22 \\
\hline Insentif & 2 & 3,64 & 2 & 3,64 & 33 & 60,00 & 18 & 32,72 & - & - & 3,22 \\
\hline Tunjangan & - & - & 3 & 5,46 & 35 & 63,64 & 17 & 30,90 & - & - & 3,25 \\
\hline Pengakuan & - & - & 2 & 3,64 & 32 & 58,18 & 21 & 38,18 & - & - & 3,35 \\
\hline Fasilitas & - & - & 5 & 9,09 & 36 & 64,45 & 14 & 26,46 & - & - & 3,16 \\
\hline
\end{tabular}

Berdasarkan Tabel 9, dapat diketahui bahwa indikator yang paling dominan/besar dalam membentuk variabel kompensasi pada Kantor Kementerian Agama Kabupaten Bulukumba adalah indikator pengakuan dengan nilai rata-rata 3,35, kemudian diikuti oleh indikator tunjangan yang sesuai dengan nilai rata-rata 3,25, indikator gaji yang adil dan insentif yang memadai dengan nilai rata-rata masing-masing 3,22. Indikator yang paling terkecil dalam membentuk variabel kompensasi adalah indikator fasilitas yang baik dengan nilai rata-rata 3,16.

Tabel 10. Deskripsi jawaban responden terhadap variabel kinerja

\begin{tabular}{|c|c|c|c|c|c|c|c|c|c|c|c|}
\hline \multirow{3}{*}{ Indikator } & \multicolumn{11}{|c|}{ Frekuensi jawaban responden } \\
\hline & \multicolumn{2}{|c|}{ STS (1) } & \multicolumn{2}{|c|}{${ }^{\text {TS }}$} & \multicolumn{2}{|c|}{ CS (3) } & \multicolumn{2}{|r|}{ S (4) } & \multicolumn{2}{|c|}{ SS (5) } & \multirow[t]{2}{*}{ Mean } \\
\hline & $F$ & $\%$ & $F$ & $\%$ & $\mathrm{~F}$ & $\%$ & $\bar{F}$ & $\%$ & $F$ & $\%$ & \\
\hline Kuantitas Kerja & - & - & - & - & 32 & 58,18 & 23 & 41,82 & - & - & 3,42 \\
\hline Kualitas Kerja & - & - & - & - & 37 & 67,28 & 18 & 32,72 & - & - & 3,33 \\
\hline Ketepatan waktu & - & - & 2 & 3,64 & 32 & 58,18 & 21 & 38,18 & - & - & 3,35 \\
\hline Kecakapan & - & - & 2 & 3,64 & 26 & 47,27 & 27 & 50,09 & - & - & 3,45 \\
\hline Semangat kerjasama & - & - & 3 & 5,46 & 32 & 58,18 & 20 & 36,36 & - & - & 3,31 \\
\hline
\end{tabular}

Berdasarkan Tabel 10, dapat diketahui bahwa indikator yang paling dominan/besar dalam membentuk variabel kinerja pada Kantor Kementerian Agama Kabupaten Bulukumba adalah indikator kecakapan dengan nilai rata-rata 3,45, kemudian diikuti oleh indikator kuantitas kerja dengan nilai ratarata 3,42, kemudian indikator ketepatan waktu dengan nilai rata-rata 3,35, kemudian indikator kualitas kerja dengan nilai rata-rata 3,33. Indikator yang paling terkecil dalam membentuk variabel motivasi adalah indikator semangat kerjasama dengan nilai rata-rata 3,31, sehingga indikator tersebut perlu ditingkatkan agar mampu mendukung dalam variabel motivasi guna meningkatkan kinerja pegawai.

\section{Pengujian Instrumen}




\section{Uji Validitas}

Uji validitas adalah untuk mengukur valid atau tidaknya suatu kuisioner. Suatu kuisioner dikatakan valid jika pertanyaan pada kuisioner mampu untuk mengungkapkan sesuatu yang akan diukur oleh kuisioner tersebut. Jika rhitung > rtabel, dimana rtabel sebesar 0,265 maka instrumen atau item-item pertanyaan berkorelasi signifikan terhadap skor total (dinyatakan valid). Hasil pengujian validitas untuk masing-masing variabel yaitu kinerja, motivasi, kompetensi dan kompensasi dengan menggunakan SPSS 24.00. Untuk validitas variabel kinerja disajikan sebagai berikut :

Tabel 11. Hasil uji validitas variabel kinerja

\begin{tabular}{|c|c|c|c|}
\hline Pertanyaan & r hitung & r tabel & Keterangan \\
\hline Y1 & 0,549 & 0,265 & Valid \\
\hline Y2 & 0,646 & 0,265 & Valid \\
\hline Y3 & 0,560 & 0,265 & Valid \\
\hline Y4 & 0,877 & 0,265 & Valid \\
\hline Y5 & 0,744 & 0,265 & Keterangan \\
\hline Pertanyaan & r hitung & r tabel & Valid \\
\hline X1.1 & 0,685 & 0,265 & Valid \\
\hline X1.2 & 0,695 & 0,265 & Valid \\
\hline X1.3 & 0,733 & 0,265 & Valid \\
\hline X1.4 & 0,796 & 0,265 & Keterangan \\
\hline X1.5 & 0,814 & 0,265 & Valid \\
\hline Pertanyaan & r hitung & r tabel & Valid \\
\hline X3.1 & 0,900 & 0,265 & Valid \\
\hline X3.2 & 0,896 & 0,265 & Valid \\
\hline X3.3 & 0,744 & 0,265 & Valid \\
\hline
\end{tabular}

Berdasarkan Tabel 11, hasil pengujian validitas untuk variabel kinerja dengan 5 butir pertanyaan menunjukkan validitas dengan nilai $r$-hitung $>r$ tabel sebesar 0,265 . Untuk variabel motivasi dengan 5 butir pertanyaan menunjukkan validitas dengan nilai rhitung $>$ r-tabel sebesar 0,265 . variabel kompetensi dengan 5 butir pertanyaan menunjukkan validitas dengan nilai rhitung $>r$ tabel sebesar 0,265 . Variabel kompensasi dengan 5 butir pertanyaan menunjukkan validitas dengan nilai rhitung $>r-$ tabel sebesar 0,265. Untuk uji reabilitas ini akan digunakan teknik cronbach alpha, jika suatu konstruk/variabel dikatakan reliabel jika memberikan nilai cronbach alpha $>0,6$. Hasil pengujian reabilitas untuk masing-masing variabel yaitu gaya kepemimpinan, motivasi dan lingkungan kerja sebagai berikut:

Tabel 12. Hasil uji reabilitas variabel-variabel penelitian

\begin{tabular}{|c|c|c|c|c|}
\hline No. & Variabel & Alpha Cronbach & Standar reliabel & Keterangan \\
\hline 1 & $\mathrm{X} 1$ & 0,797 & 0,600 & Reliabel \\
\hline 2 & $\mathrm{X} 2$ & 0,729 & 0,600 & Reliabel \\
\hline 3 & $\mathrm{X} 3$ & 0,880 & 0,600 & Reliabel \\
\hline 4 & $\mathrm{Y}$ & 0,708 & 0,600 & Reliabel \\
\hline
\end{tabular}

Berdasarkan Tabel 12, hasil pengujian reabilitas untuk variabel penelitian yaitu kinerja $(Y)$, gaya kepemimpinan (X1), motivasi (X2) dan lingkungan kerja (X3) dikatakan reliabel karena alpha cronbach $>0,6$ sehingga layak ke pengujian selanjutnya.

\section{Pengujian Hipotesis}

Pada hasil uji sebelumnya yaitu uji asumsi klasik yang meliputi uji normalitas, uji autokorelasi, uji multikolinieritas, menunjukkan bahwa regresi berganda telah memenuhi syarat asumsi klasik, sehingga diharapkan hasilnya akan baik dalam menganalisis pengaruh motivasi, kompetensi dan kompensasi terhadap kinerja pegawai Kantor Kementerian Agama Kabupaten Bulukumba. Pengujian hipotesis yang dilakukan pada penelitian ini bertujuan untuk melihat bagaimana pengaruh variabel independen terhadap variabel dependen dengan uji-t. Uji t dilakukan untuk mengetahui pengaruh 
masing-masing variabel independen yaitu motivasi, kompetensi dan kompensasi secara parsial terhadap variabel dependen yaitu kinerja pegawai apabila thitung $>$ ttabel menunjukkan diterimanya hipotesis yang diajukan. $t_{\text {hitung }}>t_{\text {tabel }}$ berarti $\mathrm{H}_{0}$ ditolak dan menerima $\mathrm{H}_{1} t_{\text {hitung }}>t_{\text {tabel }}$ berarti $\mathrm{H}_{0}$ diterima dan menolak $\mathrm{H}_{1}$. Uji-t juga bisa dilihat pada tingkat signifikasinya. Jika tingkat signifikansi $<0,05$, maka $\mathrm{H}_{0}$ ditolak dan $\mathrm{H}_{1}$ diterima. Jika tingkat signifikansi $>0,05$, maka $\mathrm{H}_{0}$ diterima dan $\mathrm{H}_{1}$ ditolak. Pengelolaan data dilakukan dengan program SPSS versi 24.0 dengan hasil sebagai berikut :

Tabel 13. Hasil Uji-t

\begin{tabular}{|c|c|c|c|c|c|c|}
\hline \multirow{2}{*}{\multicolumn{2}{|c|}{ Model }} & \multicolumn{2}{|c|}{ Unstandardized Coefficients } & \multirow{3}{*}{$\begin{array}{c}\text { Standardized } \\
\text { Coefficients } \\
\text { Beta } \\
\end{array}$} & \multirow[t]{2}{*}{$\mathrm{t}$} & \multirow[t]{2}{*}{ Sig. } \\
\hline & & B & Std. Error & & & \\
\hline \multirow{4}{*}{1} & (Constant) & 4.236 & 1.847 & & 2.293 & .026 \\
\hline & Motivasi & .231 & .110 & .251 & 2.102 & .040 \\
\hline & Kompetisi & .289 & .141 & .276 & 2.051 & .045 \\
\hline & Kompensasi & .241 & .107 & .331 & 2.250 & .029 \\
\hline
\end{tabular}

Berdasarkan Tabel 13, maka hasil yang diperoleh dimasukkan dalam persamaan regresi linear berganda sebagai berikut :

$$
Y=4,236+0,231 X 1+0,289 X 2+0,241 X 3
$$

Berdasarkan persamaan regresi linear berganda tersebut dapat dijelaskan sebagai berikut :

a. Koefisien regresi dari motivasi (X1) sebesar 0,231 dapat diartikan bahwa motivasi berpengaruh positif terhadap kinerja pegawai. Hal ini menunjukkan bahwa dengan motivasi yang tinggi, maka akan meningkatkan kinerja pegawai pada Kantor Kementerian Agama Kabupaten Bulukumba.

b. Koefisien regresi dari kompetensi (X2) sebesar 0,289 dapat diartikan bahwa kompetensi berpengaruh positif terhadap kinerja pegawai. Hal ini menunjukkan bahwa dengan kompetensi yang memadai, maka akan meningkatkan kinerja pegawai pada Kantor Kementerian Agama Kabupaten Bulukumba.

c. Koefisien regresi dari kompensasi (X3) sebesar 0,241 memberikan arti bahwa kompensasi berpengaruh positif terhadap kinerja pegawai. Hal ini menunjukkan bahwa dengan kompensasi yang memadai, maka akan meningkatkan kinerja pegawai pada Kantor Kementerian Agama Kabupaten Bulukumba.

Selanjutnya koefisien korelasi dan determinasi digunakan untuk mengetahui seberapa besar pengaruh variabel-variabel independen terhadap variabel dependen. Nilai koefisien determinasi untuk variabel independen digunakan Adjusted R Square sebagai berikut :

Tabel 14. Hasil perhitungan koefisien korelasi dan determinasi

\begin{tabular}{|l|c|c|c|c|}
\hline Model & $\mathrm{R}$ & R Square & Adjusted R Square & Std. Error of the Estimate \\
\hline 1 & $.741 \mathrm{a}$ & .549 & & .523 \\
\hline \multicolumn{2}{|l|}{ a. Predictors: (Constant), Kompensasi, Motivasi, Kompetisi } \\
\hline
\end{tabular}

Berdasarkan Tabel 14, dapat diketahui bahwa pengaruh antara variabel independen (Motivasi, Kompetensi dan Kompensasi) terhadap variabel dependen (Kinerja Pegawai) diperoleh nilai $\mathrm{R}=0,741$ yang berarti positif dan mendekati 1 , sehingga dapat disimpulkan bahwa terdapat pengaruh signifikan antara Motivasi (X1), Kompetensi (X2), dan Kompensasi (X3) terhadap Kinerja pegawai (Y) Kantor Kementerian Agama Kabupaten Bulukumba sebesar 74,1 \%. Selanjutnya dapat diketahui bahwa nilai R Square sebesar 0,549 yang berarti bahwa pengaruh antara Motivasi, Kompetensi dan Kompensasi terhadap kinerja pegawai Kantor Kementerian Agama Kabupaten Bulukumba sebesar 54,9 \%. Hal ini menunjukkan bahwa variabel independen mempunyai kemampuan untuk mempengaruhi variabel dependen sebesar 54,9 \% dan sisanya 45,1\% dipengaruhi oleh faktor lain diluar variabel Motivasi, Kompetensi dan Kompensasi. Uji F dilakukan untuk mengetahui pengaruh simultan dari variabel independen yaitu Motivasi, Kompetensi dan Kompensasi terhadap variabel dependen yaitu kinerja. Pengaruh dari ketiga variabel independen tersebut terhadap variabel dependen ditunjukkan sebagai berikut : 
Tabel 15. Tabel Uji-F

\begin{tabular}{|l|l|l|l|l|l|r|}
\hline \multicolumn{2}{|c|}{ Model } & Sum of Squares & df & Mean Square & F & Sig. \\
\hline \multirow{3}{*}{1} & Regression & 97.475 & 3 & 32.492 & 20.700 & $.000 \mathrm{~b}$ \\
\cline { 2 - 7 } & Residual & 80.052 & 51 & 1.570 & & \\
\cline { 2 - 7 } & Total & 177.527 & 54 & & & \\
\hline \multicolumn{2}{l|}{ a. Dependent Variable: Kinerja } \\
b. Predictors: (Constant), Kompensasi, Motivasi, Kompetisi \\
\hline
\end{tabular}

Berdasarkan pada Tabel 15, dapat diketahui bahwa nilai Fhitung $(20,700)>$ nilai Ftabel yaitu 2,790 dengan signifikansi sebesar 0,000 $<0,05$. Hal ini berarti bahwa variabel independen yaitu Motivasi, Kompetensi dan Kompensasi berpengaruh secara simultan terhadap variabel dependen yaitu kinerja. Pengujian hipotesis secara parsial dilakukan dengan menggunakan uji $t$, yaitu menguji pengaruh parsial antara variabel independen terhadap variabel dependen dengan asumsi bahwa variabel lain dianggap konstan. Pengaruh dari masing-masing variabel independen tersebut terhadap kinerja ditunjukkan pada tabel 18, maka dapat dijelaskan sebagai berikut:

a. Pada variabel motivasi (X1) diperoleh nilai signifikansi yaitu $0,040<0,050$, maka secara statistik pengaruh motivasi terhadap kinerja adalah signifikan. Artinya variabel motivasi berpengaruh positif terhadap kinerja pegawai Kantor Kementerian Agama Kabupaten Bulukumba. Dengan demikian hipotesis pertama penelitian ini diterima.

b. Pada variabel kompetensi (X2) diperoleh nilai signifikansi yaitu $0,045<0,050$, maka secara statistik pengaruh kompetensi terhadap kinerja adalah signifikan. Artinya variabel kompetensi berpengaruh positif terhadap kinerja pegawai Kantor Kementerian Agama Kabupaten Bulukumba. Dengan demikian hipotesis kedua penelitian ini diterima.

c. Pada variabel kompensasi (X3) diperoleh nilai signifikansi yaitu $0,029<0,050$, maka secara statistik pengaruh kompensasi terhadap kinerja adalah signifikan. Artinya variabel kompensasi berpengaruh positif terhadap kinerja pegawai Kantor Kementerian Agama Kabupaten Bulukumba. Dengan demikian hipotesis ketiga penelitian ini diterima.

\section{E. Pembahasan}

Berdasarkan tujuan penelitian ini yaitu untuk mengetahui dan menganalisis pengaruh Motivasi, Kompetensi dan Kompensasi terhadap kinerja pegawai Kantor Kementerian Agama Kabupaten Bulukumba. Adapun pembahasannya sebagai berikut :

\section{Pengaruh Motivasi Terhadap Kinerja Pegawai}

Hasil pengujian hipotesis telah membuktikan bahwa terdapat pengaruh positif dan signifikan antara motivasi dan kinerja pegawai yang diperoleh melalui hasil perhitungan yaitu nilai thitung 2,102 $>$ nilai ttabel 2,007 dengan signifikansi sebesar 0,040 < 0,050. Hal ini menunjukkan bahwa variabel motivasi secara parsial berpengaruh signifikan terhadap variabel kinerja. Berdasarkan atas nilai koefisiaen regresi sebesar 0,231 mengindikasikan pengaruh positif. Artinya semakin tinggi tingkat motivasi pegawai, akan semakin meningkat kinerja pegawai pada Kantor Kementerian Agama Kabupaten Bulukumba. Pengaruh signifikan variabel motivasi ditentukan oleh indikator yang membentuknya yaitu: kebutuhan fisiolgis, kebutuhan rasa aman, kebutuhan sosial, kebutuhan penghargaan dan kebutuhan aktualisasi diri. Kelima indikator dalam membentuk variabel motivasi telah maksimal sehingga dinyatakan mampu mendukung peningkatan kinerja pegawai pada Kantor Kementerian Agama Kabupaten Bulukumba. Sehubungan dengan kelima indikator tersebut, indikator yang dominan dalam membentuk variabel motivasi pada Kantor Kementerian Agama Kabupaten Bulukumba adalah indikator kebutuhan rasa aman dengan nilai rata-rata 3,36 dimana kebutuhan rasa aman ini adalah kebutuhan akan keselamatan dan perlindungan dari kerugian fisik maupun emosional. Seperti dengan adanya bagian keamanan berupa satpam dan petugas kebersihan akan mempengaruhi perasaan aman bagi pegawai, kemudian dengan rekan-rekan kerja yang memiliki sikap saling tolong menolong, menjunjung tinggi rasa persaudaraan juga akan meningkatkan rasa aman dan nyaman bagi semua pegawai. Kemudian diikuti oleh indikator kebutuhan fisiologis dengan nilai rata-rata 3,33, 
kebutuhan ini berupa kebutuhan makan, minum, dan kebutuhan lainnya. Seperti dengan tersedianya kantin dalam lingkungan kantor akan mempermudah pegawai untuk makan, dan didalam kantor disediakan berupa air minum, sehingga pegawai tidak lagi jauh keluar dari lingkungan kantor ketika hendak makan dan minum sehingga mengefisienkan waktu pegawai dalam bekerja. Kemudian dengan tersedianya sarana ruangan yang nyaman berupa ruangan yang ber $\mathrm{AC}$, ruangan yang rapih dan bersih akan menunjang pegawai tersebut merasa kebutuhan fisiologisnya terpenuhi, dan akan menunjang kinerja pegawai tersebut. Kemudian indikator penghargaan dengan nilai rata-rata 3,27, penghargaan berupa kebutuhan untuk dihormati dan dihargai orang lain. Seperti dengan saling menyapa hanya sekedar menanyakan kabar dan menucapkan selamat pagi bagi sesama pegawai, dan pimpinan yang selalu menyapa semua pegawainya dan memberikan semangat. Ketika ada pegawai yang mencapai target atau hendak menyelesaikan pekerjaan tepat waktu pimpinan dan rekan sesama pegawai memberikan ucapan selamat dan rasa bangga, hal ini akan menunjang peningkatan kinerja pegawai. Kemudian indikator aktualisasi diri dengan nilai rata-rata 3,25 hal ini mencakup kebutuhan menggunakan kemampuan dan potensi. Kebutuhan untuk berpendapat dengan mengemukakan ideide memberikan penilaian dan kritik terhadap sesuatu. Seperti dalam mengadakan rapat pimpinan memberikan kebebasan berpendapat, ide, atau saran dari para pegawai yang mengikuti rapat. Dengan didengarkannya pendapat dan sara-saran yang diberikan pegawai akan membuat pegawai tersebut merasa kemampuan dan potensinya dihargai dan diterima.

Dengan demikian maka kinerja pegawai tersebut akan meningkat. Kemudian Indikator yang paling terkecil dalam membentuk variabel motivasi adalah indikator kebutuhan sosial dengan nilai rata-rata 3,11. Oleh karena itu, indikator tersebut perlu ditingkatkan dan diberdayakan secara maksimal agar mampu mendukung dalam variabel motivasi guna meningkatkan kinerja pegawai. Berdasarkan dari hasil olahan dan analisis data, diketahui bahwa hipotesis yang diajukan menyatakan bahwa motivasi berpengaruh positif dan signifikan terhadap kinerja di Kantor Kementerian Agama Kabupaten Bulukumba dapat diterima. Hasil penelitian ini juga menunjukkan bahwa motivasi adalah salah satu faktor yang berpengaruh terhadap kinerja pada Kantor Kementerian Agama Kabupaten Bulukumba. Hal ini telah sesuai dengan teori Maslow yang menyatakan bahwa setiap individu sebagai karyawan/pegawai tidak bisa melepaskan diri dari kebutuhan-kebutuhannya. Selanjutnya bahwa manusia dimotivasi oleh berbagai kebutuhan dan keinginan muncul dalam urutan hirarki. Dengan demikian terdapat hubungan yang erat dan pengaruh antara variabel motivasi dengan kinerja pegawai. Penelitian ini sejalan dengan penelitian yang dilakukan oleh Prananda Genta Reza (2016) dengan judul Pengaruh Motivasi Dan Disiplin Terhadap Kinerja Tenaga Kependidikan Fakultas Kedokteran Universitas Lampung. Penelitian ini menggunakan variabel motivasi dan disiplin sebagai variabel independen dan kinerja sebagai variabel dependen.

\section{Pengaruh Kompetensi Terhadap Kinerja Pegawai}

Hasil pengujian hipotesis telah membuktikan bahwa terdapat pengaruh positif dan signifikan antara kompetensi dan kinerja pegawai yang diperoleh melalui hasil perhitungan yaitu nilai thitung $2,051>$ nilai ttabel 2,007 dengan signifikansi sebesar 0,045 <0,050. Hal ini menunjukkan bahwa variabel kompetensi secara parsial berpengaruh signifikan terhadap variabel kinerja. Berdasarkan atas nilai koefisien regresi sebesar 0,289 mengindikasikan pengaruh positif. Artinya semakin tinggi tingkat kompetensi pegawai, akan semakin meningkat kinerja pegawai pada Kantor Kementerian Agama Kabupaten Bulukumba. Pengaruh signifikan variabel kompetensi ditentukan oleh indikator yang membentuknya yaitu: pengetahuan, karasteristik pribadi, motif, konsep diri dan keterampilan. Kelima indikator dalam membentuk variabel kompetensi telah maksimal sehingga dinyatakan mampu mendukung peningkatan kinerja pegawai pada Kantor Kementerian Agama Kabupaten Bulukumba. Sehubungan dengan kelima indikator tersebut, diketahui bahwa indikator yang dominan dalam membentuk variabel kompetensi pada Kantor Kementerian Agama Kabupaten Bulukumba adalah indikator pengetahuan dengan nilai rata-rata 3,64, misalnya pegawai mengetahui cara melakukan identifikasi belajar dan bagaimana melakukan pembelajaran yang baik sesuai dengan kebutuhan yang ada dengan efektif dan efisien ditempat kerja. Kemudian diikuti oleh indikator karasteristik pribadi dengan nilai rata-rata 3,53, dimana watak yang membuat perilaku atau bagaimana seseorang merespon sesuatu dengan cara tertentu. Contohnya seperti percaya diri dalam menjalankan tugas dan wewenang yang diberikan, kontrol diri terhadap segala sesuatu , dan ketabahan dan kesabaran dalam menghadapi 
berbagai permasalahan yang dihadapi dalam bekerja. Kemudian indikator motivasi dengan nilai ratarata 3,40, misalnya pegawai yang memiliki motivasi berprestasi secara konsisten mengembangkan tujuan-tujuan yang memberi suatu tantangan pada dirinya sendiri dan bertanggung jawab penuh untuk mencapai tujuan tersebut serta mengharapkan semacam "feedback" untuk memperbaiki dirinya. Selanjutnya indikator konsep diri dengan nilai rata-rata 3,34 Adalah sikap dan nilai yang dimiliki seseorang. Sikap dan nilai diukur melalui tes kepada responden untuk mengetahui nilai yang dimiliki seseorang dan apa yang menarik bagi seseorang untuk melakukan sesuatu. Misalnya, seseorang yang dinilai menjadi pimpinan memiliki perilaku kepemimpinan sehingga perlu adanya tes tentang leadership ability. Indikator yang paling terkecil dalam membentuk variabel kompetensi adalah indikator keterampilan dengan nilai rata-rata 3,31, sehingga indikator tersebut perlu ditingkatkan agar mampu mendukung dalam variabel kompetensi guna meningkatkan kinerja pegawai.

Berdasarkan dari hasil olahan dan analisis data, diketahui bahwa hipotesis yang diajukan menyatakan bahwa kompetensi berpengaruh positif dan signifikan terhadap kinerja di Kantor Kementerian Agama Kabupaten Bulukumba dapat diterima. Hasil penelitian ini juga menunjukkan bahwa kompetensi adalah salah satu faktor yang berpengaruh terhadap kinerja pada Kantor Kementerian Agama Kabupaten Bulukumba. Hal ini telah sesuai dengan pendapat Spencer yang menyatakan bahwa kompetensi individu merupakan karakter sikap dan perilaku, atau kemampuan individual yang relatif bersifat stabil ketika menghadapi suatu situasi di tempat kerja yang terbentuk dari sinergi antara watak, konsep diri, motivasi internal, serta kapasitas pengetahuan kontekstual. Kompetensi individu merupakan gabungan dari bakat (aptitude) dan kemampuan (ability) dimana bakat menunjukkan kapabilitas untuk belajar sesuatu dan kemampuan merujuk pada kapasitas individu untuk mengerjakan berbagai tugas dalam suatu pekerjaan. Reinhard Efraim Murbijanto (2013) dengan judul Analisi Pengaruh Kompetensi Kerja dan Lingkungan Kerja Fisik Terhadap Kinerja Pegawai Dinas Tenaga Kerja Kabupaten Bekasi. Penelitian ini menggunakan dua variabel independen yaitu kompetensi kerja dan lingkungan kerja fisik, dengan satu variabel dependen yaitu kinerja pegawai.

\section{Pengaruh Kompensasi Terhadap Kinerja Pegawai}

Hasil pengujian hipotesis telah membuktikan bahwa terdapat pengaruh positif dan signifikan antara kompensasi dan kinerja pegawai yang diperoleh melalui yaitu nilai thitung 2,250 > ttabel 2,007 dengan signifikansi sebesar 0,029 $<0,050$. Hal ini menunjukkan bahwa variabel motivasi secara parsial berpengaruh signifikan terhadap variabel kinerja. Berdasarkan atas nilai koefisien regresi sebesar 0,241 mengindikasikan pengaruh positif. Artinya semakin tinggi tingkat kompensasi pegawai, akan semakin meningkat kinerja pegawai pada Kantor Kementerian Agama Kabupaten Bulukumba.Hal ini menunjukkan bahwa kompensasi telah mampu mendukung peningkatan kinerja pegawai pada Kantor Kementerian Agama Kabupaten Bulukumba. Pengaruh signifikan variabel kompensasi ditentukan oleh indikator yang membentuknya yaitu Gaji, insentif, pengakuan, fasilitas, dan tunjangan. Sehubungan dengan kelima indikator tersebut, diketahui bahwa indikator yang dominan dalam membentuk variabel kompensasi pada Kantor Kementerian Agama Kabupten Bulukumba adalah indikator pengakuan dengan nilai rata-rata 3,35, seperti pengakuan dari pimpinan dan rekan kerja atas hasil atau prestasi yang dicapai, sehingga pegawai lebih terdorong motivasinya dalam berkerja. Pengakuan atas prestasi merupakan alat motivasi yang cukup ampuh, bahkan bisa melebihi kepuasan yang bersumber dari kompensasi langsung. Kemudian diikuti oleh indikator tunjangan yang sesuai dengan nilai ratarata 3,25 artinya setiap pegawai diberikan tunjangan sesuai ukuran yang telah ditetapkan kantor. Hal tersebut dapat dilihat dari pendidikan terakhir, lamanya bekerja, dan besarnya tanggung jawab pegawai kepada kantor. Kemudian indikator gaji yang adil dan insentif yang memadai dengan nilai rata-rata masing-masing 3,22. Alasannya Gaji yang diterima pegawai selalu tepat waktu, dan insentif yang diberikan sesuai dengan hasil kerja masing-masing pegawai. Dengan kelancaran gaji dan insetif tersebut sehingga berpengaruh terhadap kinerja pegawai di Kementrian Agama Kabupaten Bulukumba. Indikator yang paling terkecil dalam membentuk variabel kompensasi adalah indikator fasilitas yang baik dengan nilai rata-rata 3,16 seperti meja dan kursi kerja yang sudah tua, komputer yang sudah banyak rusak, sehingga indikator ini sangat perlu diperhatikan dan ditingkatkan karena akan menunjang kinerja pegawai tersebut. Berdasarkan dari hasil olahan dan analisis data, diketahui bahwa hipotesis yang diajukan menyatakan bahwa kompensasi berpengaruh positif dan signifikan 
terhadap kinerja di Kantor Kementerian Agama Kabupaten Bulukumba dapat diterima. Hasil penelitian ini juga menunjukkan bahwa kompensasi adalah salah satu faktor yang berpengaruh terhadap kinerja pada Kantor Kementerian Agama Kabupaten Bulukumba. Hal ini telah sesuai dengan Simamora (2004) yang menyatakan bahwa kompensasi dalam bentuk finansial adalah penting bagi karyawan, sebab dengan kompensasi ini mereka dapat memenuhi kebutuhannya secara langsung, terutama kebutuhan fisiologisnya. Namun demikian, tentunya pegawai juga berharap agar kompensasi yang diterimanya sesuai dengan pengorbanan yang telah diberikan dalam bentuk non finansial juga sangat penting bagi pegawai terutama untuk pengembangan karir mereka. Dhermawan dkk. (2012) dengan judul Pengaruh Motivasi, Lingkungan Kerja, Kompetensi dan Kompensasi Terhadap Kinerja Pegawai Di Lingkungan Kantor Dinas Pekerjaan Umum Provinsi Bali. Penelitian ini menggunakan empat variabel independen yaitu motivasi, lingkungan kerja, kompetensi, dan kompensasi dengan dua variabel dependen yaitu kepuasan kerja dan kinerja pegawai. Dari pembahasan yang telah dikemukakan pada bab sebelumnya, dapat ditarik kesimpulan sebagai berikut:

1) Variabel motivasi berpengaruh positif dan signifikan terhadap kinerja pegawai Kantor Kementerian Agama Kabupaten Bulukumba. Karena kebutuhan fisiologis terpenuhi seperti tersedianya kantin dalam lingkungan kantor dan ruangan yang ber $\mathrm{AC}$, dari segi kebutuhan rasa aman pegawai merasa tingkat keaman dalam berkeja sangat baik karna adanya petugas keamanan/satpam dan petugas kebersihan. Dari segi kebutuhan sosial sesama pegawai sangat saling menghargai, saling kompak, dan di sela-sela jam istirahat pegawai menyempatkan saling menyapa. Dari indikator penghargaan pegawai merasa sudah baik karena penghargaan yang diberikan sesuai dengan hasil kerja yang diberikan dan selalu mendapat dukungan dari pimpinan dan sesama rekan kerja. Dan indikator aktualisasi diri sudah menunjang kinerja pegawai, karena pegawai diberikan kebebasan berpendapat dan memberikan ide-ide disetiap kesempatan. Maka dari itu kelima Indikator motivasi berpengaruh positif dan signifikan terhadap Kinerja pegawai pada kantor Kementrian Agama Kabupaten Bulukumba.

2) Variabel kompetensi berpengaruh positif dan signifikan terhadap kinerja pegawai Kantor Kementerian Agama Kabupaten Bulukumba. Karena kelima indikator kompetensi yaitu pengetahuan, ketrampilan, karakter pribadi, konsep diri, dan motivasi sudah baik. Seperti pegawai yang memiliki semangat tinggi dalam menyelesaikan pekerjaannya, pegawai yang cepat dan cekatan dalam merespon sesuatu dan melayani konsumen yang membutuhkan pelayanan, pengetahuan pegawai yang sudah sesuai dengan penempatan pekerjaan, dan ketrampilan pegawai diberbagai hal sudah baik. Pimpinan juga sering memotivasi pegawai agar lebih giat dan bersungguh-sungguh dalam bekerja.

3) Variabel kompensasi berpengaruh positif dan signifikan terhadap kinerja pegawai Kantor Kementerian Agama Kabupaten Bulukumba. Karena gaji yang diberikan oleh pimpinan sesuai dengan tingkat pekerjaan pegawai, tunjangan-tunjangan yang diberikan sudah sesuai dan selalu tepat waktu. Pimpinan juga sesekali memberikan reward atau kegiatan kepada pegawai berupa "family gathering" untuk mempererat tali silaturahmi antar pegawai dan pimpinan, guna untuk membuat pegawai tidak merasa bosan dan jenuh terhadap pekerjaannya.

\section{Saran}

Berdasarkan simpulan yang diperoleh dalam penelitian ini, maka saran yang dapat diberikan dalam penelitian ini adalah :

1. Variabel motivasi berpengaruh positif dan signifikan terhadap kinerja pegawai, maka disarankan agar kiranya pimpinan harus mempertahankan dan terus melakukan pembenahan untuk meningkatkan kinerja pegawai Kantor Kementerian Agama Kabupaten Bulukumba.

2. Variabel kompetensi berpengaruh positif dan signifikan terhadap kinerja pegawai, maka disarankan agar kiranya pimpinan yang memiliki otoritas pembuat kebijakan harus terus 
melakukan peningkatkan dan evaluasi guna untuk meningkatkan kinerja pegawai Kantor Kementerian Agama Kabupaten Bulukumba.

3. Variabel kompensasi berpengaruh positif dan signifikan terhadap kinerja pegawai, maka kiranya pimpinan harus lebih meningkatkan kompensasi pegawai guna untuk menunjang kinerja pegawai Kementrian Agama Kabupaten Bulukumba.

\section{DAFTAR PUSTAKA}

Akob, M., Arianty, R., \& Putra, A. H. P. K. (2020). The mediating role of distribution Kahns engagement: An empirical evidence of salesforce in Indonesia. In Journal of Asian Finance, Economics and Business (Vol. 7, Issue 2, pp. 249-260). https:// doi.org/10.13106/jafeb.2020.vol7.no2.249

Alam, N., Aida, N., \& Mukhtar, A. (2021). Effect of Financial Performance on Stock-Prices in Food and Beverages Firm . Golden Ratio of Finance Management, 1(2), 61 - 74. https:/ / doi.org/10.52970/grfm.v1i2.63

Barba-Aragón, M. I., \& Jiménez-Jiménez, D. (2020). HRM and radical innovation: A dual approach with exploration as a mediator. European Management Journal, 38(5), 791-803. https://doi.org/10.1016/j.emj.2020.03.007

Basalamah, M. S. A., \& As'ad, A. . (2021). The Role of Work Motivation and Work Environment in Improving Job Satisfaction. Golden Ratio of Human Resource Management, 1(2), $94 \quad-103$. https:// doi.org/10.52970/grhrm.v1i2.54

Cahyani, K. C. D., Purnamawati, I. G. A., \& Herawati, N. T. (2015). Pengaruh Etika Profesi Auditor, Profesionalisme, Motivasi, Budaya Kerja, dan Tingkat Pendidikan Terhadap Kinerja Auditor Junior (Studi Empiris Pada Kantor Akuntan Publik di Bali). E-Journal S1 Ak Universitas Pendidikan Ganesha, 3(1).

Chuang, S.-H., \& Lin, H.-N. (2013). The roles of infrastructure capability and customer orientation in enhancing customer-information quality in CRM systems: Empirical evidence from Taiwan. International Journal of Information Management, 33(2), 271-281. https://doi.org/https:// doi.org/10.1016/j.ijinfomgt.2012.12.003

Dhermawan, A. A. N. B., Sudibya, I. G. A., \& Utama, I. W. M. (2012). Pengaruh motivasi, lingkungan kerja, kompetensi, dan kompensasi terhadap kepuasan kerja dan kinerja pegawai di lingkungan kantor Dinas Pekerjaan Umum Provinsi Bali. Matrik: Jurnal Manajemen, Strategi Bisnis Dan Kewirausahaan.

Dong, L. N. T., \& Phuong, N. N. D. (2018). Organizational justice, job satisfaction and organizational citizenship behavior in higher education institutions: A research proposition in Vietnam. Journal of Asian Finance, Economics and Business, 5(3), 113-119. https:// doi.org/10.13106/jafeb.2018.vol5.no3.113

Dwi Riyanti, B. P., Sandroto, C. W., \& Warmiyati D.W, M. T. (2016). Soft Skill Competencies, Hard Skill Competencies, and Intention to Become Entrepreneur of Vocational Graduates. International Research Journal of Business Studies, 9(2), 119-132. https:// doi.org/10.21632/irjbs.9.2.119-132

Gani, A. A. (2020). Pengaruh Gaya Kepemimpinan Transformasional Dan Kepuasan Kerja Terhadap Kinerja Pegawai. CELEBES EQUILIBRUM JOURNAL, 1(2), 12-22.

Guan, Y., Yang, W., Zhou, X., Tian, Z., \& Eves, A. (2016). Predicting Chinese human resource managers' strategic competence: Roles of identity, career variety, organizational support and career adaptability. Journal of Vocational Behavior, 92, 116-124. https://doi.org/10.1016/j.jvb.2015.11.012

Haerani, S., Sumardi, Hakim, W., Hartini, \& Putra, A. H. P. K. (2020). Structural Model of Developing Human Resources Performance: Empirical Study of Indonesia States Owned Enterprises. The Journal of Asian Finance, Economics and Business, 7(3), 211-221. https://doi.org/10.13106/jafeb.2020.vol7.no3.211

Hair, J. F., Henseler, J., Dijkstra, T. K., \& Sarstedt, M. (2014). Common beliefs and reality about partial least squares: comments on Rönkkö and Evermann.

M., O. S. (2016). The link between e-HRM use and HRM effectiveness: an empirical study. Personnel Review, 45(6), 1281-1301. https:// doi.org/10.1108/PR-04-2015-0111

Mahmoud, M. A., Blankson, C., \& Hinson, R. E. (2017). Market orientation and corporate social responsibility: towards an integrated conceptual framework. International Journal of Corporate Social Responsibility, 2(1), 1-15. https:// doi.org/10.1186/s40991-017-0020-1

Maslow, A. . (1954). NoMotivation and Personality. Harper \& Row.

Mulang, H. (2021). The Effect of Competences, Work Motivation, Learning Environment on Human Resource Performance. Golden Ratio of Human Resource Management, 1(2), $84 \quad$ - 93. https://doi.org/10.52970/grhrm.v1i2.52

Pratama, A. . (2015). Pengaruh kompensasi terhadap kinerja karyawan (Studi pada karyawan PT. Asuransi Jiwasraya persero regional office Malang). Jurnal Administrasi Bisnis, 25(1).

Setiawan, Y. G., \& Latrini, M. Y. (2016). Pengaruh Kecerdasan Emosional, Kecerdasan Spiritual, Kecerdasan Intelektual dan Indepedensi pada Kinerja Auditor. E-Jurnal Akuntansi Universitas Udayana, 16(2), 10341062.

Sitopu, Y. B., Sitinjak, K. A. ., \& Marpaung, F. K. . (2021). The Influence of Motivation, Work Discipline, and Compensation on Employee Performance. Golden Ratio of Human Resource Management, 1(2), 72 - 83. https://doi.org/10.52970/grhrm.v1i2.79 
Spencer, L. M., \& Spencer, P. S. M. (2008). Competence at Work models for superior performance. John Wiley \& Sons.

Stone, D. L., Deadrick, D. L., Lukaszewski, K. M., \& Johnson, R. (2015). The influence of technology on the future of human resource management. Human Resource Management Review, 25(2), $216-231$. https://doi.org/10.1016/j.hrmr.2015.01.002

Sugiyono, P. (2011). Metodologi penelitian kuantitatif kualitatif dan R\&D. Alpabeta, Bandung.

Syafitry Sitorus, D., Amelia Putri, A. ., Rahmat Hidayat, P., \& Rostina, C. F. . (2021). The Influence of Selection, Motivation and Utilization of Information System Academic for Lecturer (SIAD) on the Lecturer Performance . Golden Ratio of Human Resource Management, 1(2), 61 - 71. https:// doi.org/10.52970/grhrm.v1i2.78

Tara, L. (2015). Pengaruh Intellectual Capital Dalam Kinerja Keuangan Dan Nilai Perusahaan (Studi Empirik Pada Perusahaan Industri Sektor Konsumsi Yang Go Public Di Bursa Efek Indonesia Tahun 2008-2012). Business Accounting Review, 3(1), 33-44.

Wahyuni, D. U. (2008). Pengaruh Motivasi, Persepsi Dan Sikap Konsumen Terhadap Keputusan Pembelian Sepeda Motor Merek "Honda" Di Kawasan Surabaya Barat. Jurnal Manajemen Dan Wirausaha, 10(1), 30-37. https://doi.org/10.9744/jmk.10.1.pp.30-37 